Ervin Budiselic and Dalibor Kraliik

\title{
Relationship between the ,Table' and the ,Altar' in the Theology and Ecclesial Practice of the Catholic Church and Evangelical Churches
}

\section{Razmerje med ,mizo' in ,oltarjem'v teologiji in eklezi- alni praksi Katoliške Cerkve in evangeličanskih Cerkva}

Abstract. Both the Catholic Church and Evangelical Churches celebrate the Eucharist; however, they differ extensively in theology and practice. What both traditions have in common is the fact that the Eucharist is removed from the context of a meal. The purpose of this article is to explore how these two traditions comprehend the connection between the table and the cross, the meal and the sacrifice, in the light of the fact that today our celebration of the Eucharist comes after the event of Jesus' cross. In other words, we want to detect the Jewish roots of the Eucharist and in a comparative analysis see how Christian and Jewish traditions have interpreted this relationship between the meal and the sacrifice, between the table and the altar. In the second section, we explore the relationship between the altar and the table in the Catholic Church, and in the third section, we do the same thing for Evangelical Churches. In the fourth section, we compare the Eucharistic theology and ecclesial practice of the Catholic Church and Evangelical Churches. We reach the conclusion that there are major irreconcilable differences in the theology of the Eucharist between the Catholic Church and Evangelical Churches, but in practice, both traditions take a similar, altar' approach. The Catholic Church is faithful to its teaching and understanding of the Eucharist, while Evangelical Churches display inconsistency when they treat the Eucharist as ,a table', but observe it more like ,an altar'.

Key words: Eucharist, altar, table, meal, Catholic Church, Evangelical Churches

Povžetek: Tako katoliška Cerkev kakor tudi evangeličanske Cerkve obhajajo evharistijo, vendar se tu močno razlikujejo v teologiji in praksi. Kar imata obe izročili skupnega, je dejstvo, da je evharistija vzeta iz konteksta obeda. Namen članka je raziskati, kako ti dve izročili razumeta povezavo med mizo in križem, obedom in darovanjem, v luči dejstva, da se današnje obhajanje evharistije dogaja za dogod- 
ki Jezusovega križanja. Z drugimi besedami, v članku želimo poiskati judovske korenine evharistije in v primerjalni analizi videti, kako sta krščansko in judovsko izročilo pojasnjevala razmerje med obedom in darovanjem, mizo in oltarjem. $\mathrm{V}$ drugem delu raziskujemo razmerje med oltarjem in mizo v katoliški Cerkvi, v četrtem pa se posvečamo isti temi znotraj evangeličanskih Cerkva. V četrtem delu primerjamo evharistično teologijo in eklezialno prakso v katoliški Cerkvi in evangeličanskih Cerkvah. Sklepamo, da med katoliško Cerkvijo in evangeličanskimi Cerkvami obstajajo pomembnejše nespravljive razlike v evharistični teologiji, čeprav se v praksi obe izročili zatekata k podobnemu ,oltarnemu‘ pristopu. Katoliška Cerkev je zvesta svojemu nauku in razumevanju evharistije, medtem ko evangeličanske Cerkve izražajo nedoslednost, kadar evharistijo obravnavajo kot ,mizo', vendar nanjo gledajo bolj kot na ,oltar'.

Ključne besede: evharistija, oltar, miza, obed, katoliška Cerkev, evangeličanske Cerkve

\section{Introduction}

In theology and ecclesial practice of the Evangelical Churches, ${ }^{1}$ the Eucharist is a symbolic ritual. Christ is not present in any way in the elements of the bread and

1 The label ,evangelical' has a long history of usage. Accordingly, Luther used it for all Christians who accepted the doctrine of sola gratia; by 1700 , throughout Europe, the term had become a simple synonym for ,Protestant' or, in German-speaking areas, ,Lutheran' (World Council of Churches). During the $18^{\text {th }}$ and $19^{\text {th }}$ centuries the term ,evangelical' was connected with religious revival or awakenings in Britain and American colonies, hence »evangelicalism became a synonym for revivalism, or a fervent expression of Christianity marked by an emphasis on converting outsiders" (Merritt 2015). Therefore, the term ,evangelical' can be used to describe a) the ,Evangelical movement' which is rooted in Reformation but was born out of revivals during the $18^{\text {th }}$ and $19^{\text {th }}$ centuries. This movement influenced people in various Protestant, free Evangelical Churches and even people from the Catholic Church; b) ,Evangelical believers' a label that describes people from various Churches who base their belief on the gospel (Anglicans, Reformed, Lutheran, etc.); c) ,Evangelical Churches' Churches that inherited teachings from the Lutheran Reformation saying only Scripture, grace and faith are the foundation of man's relationship with God, as well as from the radical wing of Reformation teaching on discipleship saying that only an adult can be baptized, all should have a zeal for evangelization, church and state should be separated, and each local church is the church in its full sense because the Word of God is preached and the Holy Spirit is present. History and theology of evangelical Churches in Croatia is best presented in the books Crkve reformacijske baštine u Hrvatskoj [Churches of the Reformation Heritage in Croatia] (Jambrek 2003) and Leksikon evanđeoskoga kršćanstva [Dictionary of Evangelical Christianity] (Jambrek 2007). Writing from the Croatian context, the term ,evangelical' in this article is used more narrowly referring only to the free Evangelical Churches (Olson 2005, 230) or ,the Churches of the Reformation heritage' which according to Jambrek $(2008,154)$ in Croatia include: "Evanđeoska pentekostna crkva [Evangelical Pentecostal Church], Savez baptističkih crkava [Baptist Union], Vijeće Kristovih crkava [Council of the Churches of Christ], Savez Kristovih pentekostnih crkava [Union of Christ's Pentecostal Churches], Crkva Božja [Church of God], Savez crkava ,Riječ Života' [Union of Churches ,Word of Life'] and some small denominations and independent local Christian communities. " Since Pentecostal and Baptist Churches are the largest Churches among the Evangelical Churches in Croatia, we have chosen to focus on the practice of the Eucharist in these two traditions. However, a problem arises in the Croatian language because there is, Evangelička crkva' which stands for the Lutheran Church, while there are also ,Evanđeoske crkve', that is, Evangelical Churches. Although they share the same adjective, these Churches are distinct in terms of their history, theology and practice. Additionally, even though ,Evangelical Churches' or ,the Churches of the Reformation heritage' are viewed by the official ecclesiological teaching of the Catholic Church as ,ecclesial Communities' they consider themselves full and 
wine, and these elements only symbolically represent Christ's body and blood. In theology and practice of the Catholic Church, however, the situation is different: Christ is truly, physically and spiritually, present in the Eucharistic species of the bread and wine. Hence, the Eucharist is not only a sacrament but also a sacrifice. What both traditions have in common is the fact that the Eucharist has been removed from the context of a meal. No matter how we interpret the Eucharist, it was founded in the context of the Passover meal before the event of the cross with a view on the upcoming passion; therefore, the language of both sacrifice and meal is present. Consequently, in the context of the Eucharist, we can talk about the ,altar' (sacrifice) and the ,table' (meal).

But what is the connection between the table and the cross, the meal and the sacrifice, since today our celebration of the Eucharist comes after the event of the cross? The purpose of this article is not to argue for a particular view of Christ's presence in the Eucharist or to trace historical reasons for the development of these two traditions, but to detect Jewish roots of the Eucharist and in a comparative analysis understand how these two traditions have interpreted the relationship between the meal and the sacrifice, between the table and the altar. It is important to note that unlike in Catholic theology, it is not possible to argue for one particular view or Eucharistic theology within Evangelical Churches. Therefore, even though we will present general sketches of the Eucharistic theology of Evangelical Churches, the interpretation of the relationship between the table and the altar will reflect our view of it.

\section{Jewish roots of the Eucharist}

As we consider the relationship between the table and the altar, the starting point is to consider the Jewish roots of the Eucharist. According to Gregory Dix (Jones and Kessler 2005, 147), "the most important thing we have learned about the liturgy in the past 50 years is that Jesus was a Jew «, and by that he meant that Christian worship makes little sense without an understanding of the Jewish liturgical matrix out of which it came. In order to grasp the ,Jewishness' of the Eucharist, its sacrificial and communal aspects, we will first consider the form of the Eucharist as a meal and its rich Jewish theological background.

\subsection{The Eucharist in the context of a full meal}

Jesus' Last Supper was a full meal. But what was the meal during which Jesus spoke about his body and blood? Was it a traditional Passover Seder, a kind of a memorial dinner or a fellowship meal? Gillian Feeley-Harnik $(1994,113)$ says:

proper Churches. Their ecclesiology is based on their understanding of the biblical stipulations stating what makes a particular group of believers in Jesus a ,church.' Moreover, in terms of legal or social standing in Croatia, Evangelical Churches, as well as other religious communities, are based on the Contract with the Croatian Government from 2003 and are recognized as ,Churches.' Based on this and on other abovementioned arguments, in this article we will use the term ,Churches' when we speak about ,Evangelical Churches.' 
"None of these authors describes (sic) a last supper that can be identified with any one traditional Jewish meal. In fact, their descriptions seem to combine elements of many kinds of meals, which is not surprising." She suggests that the Last Supper could also resemble the kiddush rite that was practiced every Sabbath as well as on the annual feast days (115).

According to the synoptics, the Last Supper was a Passover Seder that occurred the night before the crucifixion on the fifteenth day of the month of Nisan - the first day of Passover. But according to John, the Last Supper and the crucifixion occurred on the fourteenth of Nisan, on the ,preparation day' before the day of Passover. None of the New Testament writers give us a full account of that Supper, only fragments. Paul in 1 Corinthians, probably as the first written account of the Supper, mentions bread, a cup (of wine) and the command to take both elements in ,remembrance of me'. The focus of Paul's account is on the proclamation of the Lord's death and his second coming. Mark and Matthew both mention bread and a cup, but also add a speech about the blood of the covenant and the idea that Jesus will not drink wine until the day when he will drink it anew in the kingdom of God. They do not mention the need for remembrance. Luke's account is quite extensive because he mentions one cup before the bread and connects that cup with the statement of not drinking again until the kingdom comes. Then Luke mentions bread and the command to "do this in remembrance of me", and adds another cup after the supper which Jesus connects with the »new covenant in my blood".

As we step into the time after Jesus' ascension, the Eucharist was also practiced in the context of a full meal. Speaking of Acts 2:46, Yizchak Kugler $(2008,19)$ says that the breaking of bread was an integral part of their meals together, so the Eucharist was not a separate ceremony from the ,breaking of bread' or ,love feast ' (Jude 12). This sharing of food occurred in the homes of believers, and because the early Church in Jerusalem numbered in thousands, it would have been impossible for all of them to go together from house to house and fit into one single residence. In Acts 20, believers also gathered to break bread; however, rather than it being an open meeting, it was an intimate celebration for the family of believers. A common meal was also characteristic of the gathering in Corinth, or possibly even the purpose of it (1 Cor 11:33), but we also know that the Eucharist was observed in the midst of it. Accordingly, Paul does not forbid eating and drinking in the context of the Eucharist, but only regulates misbehavior of the Corinthian believers.

Even though the Eucharist in the early Church was practiced as a part of a full meal, as a subset of ,agape' meals, in both the Catholic and Evangelical traditions this is not the case today. ${ }^{2}$ Regardless what the reasons for this are and whether

\footnotetext{
Andrew McGowan $(1999,12)$ offers a survey of Eucharistic practices in the first few hundred years of early Christianity. Arguing for the diversity of practices, including the usage of food, McGowan says: "Since, as will become evident, I do not understand early Christian meal practice as unitary in form, it is not my primary concern to suggest that this was always the case; but a number of instances will be considered further in which it is difficult or impossible to say that the eucharistic meal does not consist of a real or substantial meal. In these cases, at least, it will therefore be quite evident that the category of 'meal' can and should be employed in analysis of the texts and practices."
} 
they are justified, both traditions connect the Eucharist with sacrifice and fellowship (meal) by offering various explanations and interpretations. Before we discuss how each tradition views this relationship between the altar and the table in the next section, our focus now turns to the rich Jewish theological background of the Eucharist.

\subsection{Jewish theological background of the Eucharist}

Brant Pitre provides an extensive and elaborated description of the rich theological Jewish background of the Eucharist, and we will, therefore, rely on his remarks. Accordingly, Pitre describes the Eucharist as the new exodus and new Passover, as the manna of the Messiah and as the Bread of Presence. We will briefly examine each category.

The Last Supper occurred within the context of the Passover meal, a meal that celebrated protection from death and deliverance from ,the house of slavery' Egypt. Moses led the Israelites to Sinai where God made a covenant with Israel. The exodus covenant was sealed in blood as Moses threw the blood of the covenant upon the altar. In this way, God made Israel his family, his ,flesh and blood', but the ceremony did not end there. It ended with a banquet meal that was significant because Moses and the elders went up to the mountain where they feasted in the presence of God (Ex 24:11). To keep the memory of these events, God ordered the Israelites to hold on to the Passover feast. But that Passover meal was not identical to the Jewish Passover celebrated at the time of Jesus; the Jewish tradition developed throughout approximately fifteen centuries and expanded, contracted, added or removed some elements of the celebration. ${ }^{3}$

In order to connect the Eucharist with the new manna from heaven, Pitre discusses the ancient Jewish expectation of a new manna from heaven. In the Old Testament, manna was understood as a miraculous bread from heaven, a sign of God's fidelity and a foretaste of the Promised Land. It was kept in the Ark of the Covenant, in the Holy of Holies. However, since the earthly Temple was a sort of copy or image of the heavenly Temple, the Jews also believed that the manna was kept in heaven, within the heavenly Temple of God. When the Ark of the Covenant was lost, manna continued to exist in heaven, and so the messiah, as a new Moses, would come to establish the kingdom of God, and it was expected that manna would return. Furthermore, Pitre discusses the mentioning of bread in the Lord's Prayer, arguing for the meaning of „Give us this day our supernatural bread» or "Give us this day our supersubstantial bread" and views that request as a prayer for the new manna from heaven. Additionally, Pitre also sees a reference to the Jewish hope for the new manna in Jesus' speech in John 6, claiming that the speech about eating his body and drinking his blood relates to the Last Supper. ${ }^{4}$

For example, the spreading of the lamb's blood on the doorposts of the home was abandoned and drinking of cups of wine was added.

4 'Jesus could have chosen the Passover lamb to explain the Eucharist, or the mysterious Bread of the Presence. But when he wanted to emphasize the necessity of eating his flesh and drinking his blood and the fact that it would somehow become, real food' and, real drink' he didn't choose either of 
When discussing the connection of the Eucharist with the new Bread of the Presence, Pitre $(2011,116)$ starts with this question: »If Jesus intended to inaugurate the new exodus through his death and resurrection, then how did he think God would be worshiped once the new exodus had begun? In particular, how would God be present to his people, as he had been in the past, in the Tabernacle of Moses? « The answer is the Bread of the Presence. The Bread of the Presence was one of the things that was kept inside of the Tabernacle on the golden table together with various bowls that were used for pouring sacrificial drink offerings of wine (Num 15:5-7; 28:7). This Bread, literary called ,Bread of Faces', was a visible sign of the face of God and served as a memorial of the heavenly banquet in which Moses and the elders ,saw' the God of Israel while they ,ate and drank' at the mountain. It was also a part of the unbloody sacrifices that often consisted of bread and wine, and it was also offered as a sacrifice every Sabbath day by the High Priest. ${ }^{5}$

Based on all of this, Pitre concludes that the Last Supper was also the messianic fulfilment of the Bread of the Presence. Such a rich theological background can explain why Jesus did not closely follow Passover, protocol'. Among other things, Pitre observes that during Passover Jesus did something strange: instead of speaking about the past exodus from Egypt, Jesus used the elements of bread and wine to talk about his future suffering and death and commanded the disciples to eat and drink. In this way, he established a new Passover that speaks about the new exodus - an exodus that will accomplish deliverance from death and slavery through the blood of the Lamb. Later, Apostle Paul in 1 Corinthians 5:7 said, "Christ, our Passover lamb, has been sacrificed ", which gives us the right to connect that what had happened on the cross with the Passover and the Passover meal with the Eucharist.

Hence, in Exodus we have a connection between the altar and the table - the table fellowship was the result of an altar sacrifice. As Pitre $(2011,61)$ observes, "no one living at the time of the Temple could have ever had any misconceptions about the fact that the first-century Passover was first a sacrifice and then a meal « - a meal that was not an open table, but a covenant feast only for the members of the covenant family of God. However, there is an additional link between the altar and the meal. Namely, "the sacrifice of the Passover lamb was not completed by its death. It was completed by a meal, by eating the flesh of the lamb that had been slain «. Such a sacrifice, like any other Temple sacrifices (even pagan ones as Paul would argue in 1 Corinthians 10), was aimed to bring about a communion, a fellowship between God and men. As Levering $(2005,65)$ says, "sacrifice is completed in feasting ", or we might say, "the altar is connected with the

these. He used the Jewish hope for new bread from heaven, and identified the Eucharist with the manna of the Messiah." (Pitre 2011, 102)

5 Instead of the Bread of the Presence, it is possible to offer a different interpretation of the meaning of the bread arguing that the context of Jesus' words is the ritual involving the afikoman - a piece of unleavened bread that is broken in the context of Passover seder. The meaning of this word could come from epikomen, ,that which comes after', ,dessert' or from aphikomenos, ,the One who Comes.' Hence, »the eating of the afikoman signifies the anticipation of the coming Messiah « (Yuval 2008, 246). 
table«. But how the Catholic and Evangelical traditions understand this relationship will be discussed in the following sections.

\section{Relationship between the altar and the table in the Catholic Church}

To understand the relationship between the altar and the table in the Catholic Church, in its theology and practice, we must first understand the meaning of the Eucharist and its place in the Catholic worship service (the Mass). However, before we do that, let us first present a very brief overview of the Eucharistic worship context - the Catholic Church service or the Mass.

The word ,mass' has its roots in the Latin phrase »/te, missa est". This expression is addressed in Latin to the people in the Mass of the Roman Rite at the end of the church service, and it literary means "Go, it is the dismissal " or "Go, it has been sent«. In contemporary English liturgy, it is usually replaced by the phrase "Go in peace" or the Croatian equivalent "Idite u miru«. We could say that everything occurring during Mass before its central point, the Eucharist itself, is designed to lead the believer (worshiper) to and prepare them for the receiving of the Body and Blood of their Lord Jesus Christ in the sacrament of the Eucharist.

Therefore, Mass is liturgically structured to lead the believers in the worship service into humbleness and repentance of their sins - from the very beginning of the Church service up to the very moment of the Eucharist. The priest guides the believers in the quieting of their hearts before God and focusing their thoughts on Him. Believers sing praises, give thanks and pray to the Lord for themselves, their families, their church or community and for current issues in their parish or town, their country or in the world. They quiet their hearts to listen to the Word of God, which is announced in the readings from the Holy Scripture and is proclaimed in the words of the preacher. Together with the priest they are preparing for an encounter with their Lord, with his very Body and Blood, in the species of bread and wine in the Eucharist.

In the moment of epiclesis (invocation), when the priest/celebrant is praying for the Holy Spirit to come onto the species of bread and wine by the power of the Holy Spirit and by the action of Christ, transubstantiation occurs when the inner substance of the bread and wine is changed into the Body and Blood of Jesus Christ, while the appearance of the bread and wine remain the same (Perry 1994, 123; Catechism of the Catholic Church, nr. 1353). ${ }^{6}$ The Body of Christ (sacramental bread; lat. hostia = victim, sacrifice) is then given to the people to partake in it, receive grace from the Lord and be spiritually nourished and renewed.

It should be emphasized, however, that according to John Chrysostom, wit is not man that causes the things offered to become the Body and Blood of Christ, but he who was crucified for us, Christ himself. The priest, in the role of Christ, pronounces these words, but their power and grace are God's. This is my body, he says. This word transforms the things offered. " (Catechism of the Catholic Church, nr. 1375-1376) 
Therefore, the sacrament of the Eucharist is the center of Mass, of the sacramental event, because it is

"the source and summit of all Christian life. In the Eucharist, the sanctifying action of God in our regard and our worship of him reach their high point. It contains the whole spiritual good of the Church, Christ himself, our Pasch. Communion with divine life and the unity of the People of God are both expressed and affected by the Eucharist. Through the eucharistic celebration we are united already with the liturgy of heaven and we have a foretaste of eternal life." (Compendium of the Catechism of the Catholic Church, nr. 274).

The Catholics believe that Jesus Christ is present in the Eucharist in »a unique and incomparable way", which is "a true, real and substantial way, with his Body and his Blood, with his Soul and his Divinity. In the Eucharist, therefore, there is present in a sacramental way, that is, under the Eucharistic species of bread and wine, Christ whole and entire, God and Man. " (Compendium of the Catechism of the Catholic Church, nr. 282) This is why the Eucharist holds such special meaning and importance and is so central to the Catholic believer; it is a meeting place with their Lord, a place where they can touch and feel Jesus' Body and Blood, a place where they can experience real presence and real communion with their God and God's people.

This sacramental communion is a real expression and realization of Christological and ecclesiological fellowship because wthe Eucharist is creating, strengthening and promoting the fellowship that is the essence of the Eucharist 1 , and it is the celebration of and fellowship with the whole, universal Church (Ikić 2014, 222). The partaker in the Eucharist is not alone; he is not merely an individual in a relationship with Christ, but an individual who is being transformed and incorporated into the communion of the Body of Christ, that is, into the communion of the Church. Moreover, this fellowship is daily life for all who partake in the Eucharist, in the Body of the Lord, and who are, therefore, becoming members of the same Body. According to Joseph Ratzinger, this fellowship among believers is "binding the heaven and earth, the living and the dead, the past, present and future, and opening towards eternity“ (Ratzinger 2007, 76-77; 1988, 115; 2006, 79, 150).

Furthermore, Joseph Ratzinger/Pope Benedict XVI $(2011,420)$ considers the Eucharist to be ,the sacrament of the altar', by saying that

"the daily climax of the life of a priest is the sacrament of the altar, a mysterious fraternization of the heaven and the earth, which is actualizing this sacrament. God is inviting us to his table. He wants us as his guests. He is giving himself to us. God's gift is God himself. The Eucharist is a sacred ceremonial which God himself is giving, even when external circumstances are poor: here is overstepped the threshold of the everyday life, God is celebrating with us. And this God's ceremonial is much more than a general free time, which becomes empty when there is no more a celebration 
which we ourselves can prepare. But, let us think something through: the ceremonial is coming from the sacrifice. Only the grain seed which is dying can bring the fruit.«

Now we have come to the main focus of our research, to the question of the relation between table/fellowship and altar/sacrifice. It seems Benedict XVI is certain that the sacrifice and the altar come first, and then from there arise the table and fellowship. There is no altar without a sacrifice, and the altar without a sacrifice is only a table. Therefore, the sacrifice is key for understanding the meaning of the Eucharist because "the Eucharist is the very sacrifice of the Body and Blood of the Lord Jesus which he instituted to perpetuate the sacrifice of the cross throughout the ages until his return in glory. Thus he entrusted to his Church this memorial of his death and Resurrection. It is a sign of unity, a bound of charity, a paschal banquet, in which Christ is consumed, the mind is filled with grace, and a pledge of future glory is given to us. " (Compendium of the Catechism of the Catholic Church, n. 271)

We must be careful and emphasize that in the Eucharist Christ is not sacrificing himself again. His sacrifice is not temporal; it was done once for all times, and it is not limited to one single event that happened some 2,000 years ago. Therefore, in the Eucharist Christ's sacrifice is re-proclaimed and presented anew to the people (Allison and Castaldo 2017, 106). "The sacrifice of the cross and the sacrifice of the Eucharist are one and the same sacrifice. The priest and the victim are the same; only the manner of offering is different: in a bloody manner on the cross, in an unbloody manner in the Eucharist." (Compendium of the Catechism of the Catholic Church, nr. 280)

Therefore, the Catholic Church does not consider the Eucharist as simply a commemoration »but a ceremony of prayer and feasting that is also and most importantly sacrifice, an effective reenactment of Jesus' atoning death «. This is important to point out because if in the Eucharist believers would merely receive Christ's Body and Blood under the sacramental sign, then the Eucharist would be a meal but not a sacrifice. However, the whole previously self-sacrificed Christ is present in the sacrament and then feasted by the believers. " In consecrating the body and blood of Christ, the priests of the New Covenant cause the whole Christ, in his sacrificial mode, to be present in the sacrament. " (Levering 2005, 86, 89) Similarly to Levering, Šagi-Bunić $(1973,92)$ explains that Eucharistic prayer of the gathered church is a ,sacrificial prayer of the Church', and by this prayer the Church is constituted "as the one who is presenting a sacrifice in this act of actualizing of one and only sacrifice of Christ, here and now «. The Church prays that in this offering she would be included with Christ as the bringer of the sacrifice, that she would be unified and merged with the sacrificed Christ and that she herself would become a sacrifice unto God together with Christ's sacrifice, so that all members of the community in Christ would become, a living sacrifice'. 


\subsection{Assessment of the relationship between the altar and the table in the Catholic Church}

Since the Eucharist is the focal point of the Mass and Christ is truly present in the species of the bread and wine, the Eucharist is, according to the Catholic Church, of supreme importance for the spiritual life of the Church due to the effects that it accomplishes (Turnbloom 2017, 24). ${ }^{7}$ Hence, the Eucharist is a memorial, a sacrifice and a meal (Levering 2005, 194), but it is predominately described and understood as a sacrifice. It is a sacrifice that is linked with the Lord's Table, which creates a communion.

Furthermore, since the Eucharist in the Catholic Church is primarily a sacrifice, the sacrament of the Eucharist is celebrated and approached as an altar. Or as Levering $(2005,194)$ said, "all aspects of Eucharistic theology receive their intelligibility in light of the requirement of cruciform communion «. Hence, if we talk about the meal or communion in the context of the Eucharist, it is a sacrifice that creates all of that: the Eucharist is a sacrificial meal and sacrificial communion. Thomas Aquinas defined the Eucharist as the sacrament of charity. He believed "the reality of [the Eucharist] is charity, not only as to its habit, but also as to its act, which is kindled in this sacrament " (The Summa Theologica III, q. 79, a. 4). David Farina Turnbloom $(2017,24-25)$ explained it by saying that with his statement, Aquinas claimed that the Eucharist began with charity through which the individual was united with Christ. Through this union, charity and its acts are increased in the subject, and when such an increase occurs throughout a community, this nourishes and increases the unity of that ecclesial body. Moreover, this union is understood in the following way: the reception of this active charity through the Eucharist involves human action, because spiritual life is not a state of having charity, but actions that are formed by the charity. An individual's union with Christ produces unity of the ecclesial body, because unity is measured not by virtue of each Christian's connection to Christ alone, but by virtue of how such connections enable the body to function as one. The union with Christ is ordered toward the community's union as Christ.

Based on what has previously been said, we can conclude and confirm that the Eucharist in Catholic theology and practice is an ,altar' and a ,table', although the table, which stands as a symbol for fellowship, is not connected with an actual full meal but with the idea of communion - first and foremost with Christ - which then produces a communion with others. Or as Levering said $(2005,194)$ : "The Eucharist, as thanksgiving, memorial, sacrifice, and meal, is Christ's personal and intimate action of drawing us eschatologically into his cruciform love. Sharing in this love requires, in Christ and by the power of the Holy Spirit, a radical death to self that makes possible communion with God and neighbor."

"While baptism and penance effect justification insofar as they infuse the theological virtues, the Eucharist effects sanctification insofar as it increases charity in the subject. In other words, the Eucharist deepens the spiritual life of the Church. « (Turnbloom 2017, 24) 


\section{Relationship between the altar and the table in Evangelical Churches}

To understand the relationship between the altar and the table in Evangelical Churches, first we have to understand the setting of Sunday worship services and how Evangelical Churches view Christ's presence in the Eucharist. In general, Evangelical Churches in Croatia view the proclamation of the Word as the central part of their Sunday worship service, though some Churches also emphasize singing and some the importance of the Eucharist. According to Stanko Jambrek (2003, 269-270), we can speak about two models of a Sunday worship: the Pentecostal-Charismatic and Baptist styles of worship. In the Pentecostal-Charismatic style of worship, the central aspect of worship is the activity of the Holy Spirit in the community, that is, the congregation's relationship with God through the Holy Spirit. Although the church service has some pattern (introduction, worship songs, preaching, etc.), this pattern can be ,interrupted' by the activity of the Spirit through the gifts of the Spirit. For the Baptist style of worship, Jambrek $(2003,273)$ says that the service contains various elements such as singing, preaching, prayer, collecting offerings, greetings and announcements, but at the center is the Word of God-preaching. After preaching, the service is closed with prayer, singing, a collection of offerings, a final blessing and announcements.

Regarding the issue of Christ's presence in the Eucharist, Evangelical Churches by default follow the memorialist position claimed by Zwingli. He argued that when Jesus took the bread and said " this is my body « he meant that the bread only signified his body, not that it was or would literally become his body. Based on this viewpoint, Evangelicals believe that Christ is not present in the elements of bread and wine, but that he lives in the believers who are, according to the Bible, temples of the Spirit. Hence, the focus is on Christ's presence in the believers and not in the elements themselves. Accordingly, the Eucharist is not considered a ,sacrament' or a ,means of grace', but a commemoration of Christ's death. Evangelicals "do not think they are being mystically united with Christ through eating the elements, but they do believe that the Holy Spirit uses the communion service to make Christ more vividly present in the minds and hearts of the participants" (Olson 2005, 230).

Speaking about Baptist Churches, Olson (2008b, 152) claims that some contemporary sacramentalist Baptist theologians tend to move away from the conventional Baptist understanding of the Eucharist toward the Calvinist or Reformed view when they "express a sense in which Christ is being eaten by participants in the Lord's Supper or in which the grace of God there is different in kind or degree". But in general, Baptists hold the Zwinglian view of the Eucharist, and in the context of the church service

"the Lord's Supper is a way of communing with each other and with Christ; it is a communal event of memory and proclamation that strengthens the unity of the church. /... / Just as faithful preaching communicates Christ 
and helps believers commune with him, so the Lord's Supper draws faithful participants closer to Christ and each other. The church is built up by this means as well as by others." (154)

As with the Baptists, the Pentecostal understanding of the Eucharist is basically in keeping with the Zwinglian understanding, and Veli-Matti Kärkkäinen $(2008,180-181)$ argues that the following statement represents the best explanation of what Pentecostals believe about the Eucharist:

"We seek a deeper spiritual reality as a present moment [of] experience. We do not believe superstitiously that the bread and wine actually become the physical body and blood of Christ, nor do we believe that there is any virtue in the physical elements themselves apart from their power as figures to point us to the deeper reality which they typify. We do believe, however, that an act of faith in partaking of the elements results in the real operation of the Spirit in us to strengthen us in the inner man and to heal us in our physical bodies. We, furthermore, believe that the reality which the Lord's Supper signifies is our , daily bread' of which we partake day by day."

As we can see from this statement, unlike the Baptists, Pentecostals connect the Eucharist with physical healing. Since Pentecostals believe in the ,healing in atonement ${ }^{\prime 8}$ and the Eucharist commemorating Christ's death, Pentecostal spirituality considers the Eucharist a healing event. Accordingly, healing can come through the preaching of the Word, prayer for healing, through the gift of the Spirit that consists of healing or through partaking in the Eucharist.

But what is the role of the Eucharist in the Sunday services? Even though the majority of Evangelicals hold a symbolic view of the Eucharist, the Eucharist is not mere symbolism. ${ }^{9}$ The Eucharist is an occasion for Christians to share in the benefits secured for them through Christ's salvific work and to celebrate fellowship with Christ and one with another. This last point is also evident in the process of self-examination, which is a prerequisite for entering communion where focus can be on the believer's relationship to God, relationship with other believers or both. Furthermore, the Eucharist is a ,message in a picture' - a proclamation of the Gospel's message (Christ's death and resurrection) through the reenacting of the Last Supper. Finally, it is a proclamation of Jesus' Second Coming - the eschatological messianic banquet, which is an occasion to remind believers of the hope that lies in the future and invite them to faithfulness and endurance for Christ's

8 „Physical healing, like salvation, is an inheritance of every believer through the atoning death of Christ. Using Matthew 8:16-17 to interpret Isaiah 53:4, this view concludes that Christ bore man's bodily as well as his spiritual suffering on the cross. Thus, one receives his physical healing by faith just as he receives his salvation. " (Chappell 1984, 498)

9 In responding to the Pentecostal view of the Lord's Supper, Olson (2008a, 210) says the following: »I urge Pentecostals and Baptists and other free-church Protestants to hold to their traditional understanding of the Lord's Supper as symbolic without reducing it to ,mere symbolism.' A real symbol participates in the reality it represents without becoming that reality. A gap always remains between symbol and reality, but it does not need to be a fixed gulf." 
sake. Even though Kärkkäinen $(2008,193)$ says the following in reference to Pentecostals, we believe that this statement can equally apply to all Evangelicals: "As such, the Lord's Supper expresses the fundamental equality of all God's people. Also, believers at the Table are not side by side as unrelated individuals, because the Supper is a fellowship (koinonia) meal at which the believers are present as the people of God (1 Cor 10:17)."

Even though Evangelicals share the same or similar views on the Eucharist, there is no specific pattern of how often and at what point in the Sunday worship the Eucharist is observed, because Evangelical Churches can have different traditions regarding these issues. Some Churches observe the Eucharist every week; some have it once a month; some Churches observe the Eucharist before the Word, some after, and some are flexible whether the Eucharist is observed prior to or after the preaching of the Word.

\subsection{Assessment of the relationship between the altar and the table in Evangelical Churches}

After we summarized the view of the Eucharist among Evangelical Churches, in this section we will focus on the assessment of the worship practice of the Eucharist among these Churches. The main thing that needs to be emphasized is that, due to the fact that Evangelicals hold that Christ is not physically or spiritually present in the elements of the bread and wine, theologically the Eucharist is not viewed as an ,altar' or connected with a sacrificial activity. Accordingly, the Eucharist is a table fellowship around which believers gathered because of the altar - the altar being Jesus' sacrifice on the cross and his resurrection. However, is this really the case?

For example, when discussing the practice of the Eucharist among the Churches of Christ (an Evangelical denomination) in the USA, John Mark Hicks (2010a, 165166) offers his assessment of this practice, but what he says about these Churches can be also applied to most of the Evangelical Churches in Croatia. Hicks observes that the ,table' in both its form and function is eclipsed in the 20th century, and he states the logistic reasons for this are the usage of individual communion cups, the practice of being served by deacons or others in the pews and the construction of buildings whose architecture and furniture arrangement were more auditory than participatory. However, apart from these logistic explanations, there are some theological reasons for this as well. Hicks observes that the Eucharist in the Churches of Christ is usually focused on two dimensions: ,commemorative' (memorial, monumental) and ,declarative' (testimonial, proclamation), or as he says: "We remember and we proclaim. Through this cognitive process, we contemplate the death of Christ and when we do this together we proclaim the Lord's death."

Furthermore, Hicks (2010a, 167-168) argues that the observance of the Eucharist in an evangelical denomination of today's Churches of Christ may be characterized as (1) cognitive/mental, (2) introspective/penitential, (3) vertical/individual and (4) legal. Without going into all the details of his argument, Hicks firstly says that the primary mode in which the Supper is experienced is a , solemn 
contemplation' where the worshipper remembers, reflects and visualizes the sufferings of Christ; therefore, by observing the Eucharist we commemorate the tragedy of Calvary. Secondly, Paul's instruction in 1 Corinthians 11 about »eating and drinking in an unworthy manner is understood as a time of godly fear and self-examination where ,worthiness' is understood either as participating in the Eucharist in proper spirit and attitude (properly focused on Christ) or as an opportunity for self-examination and penitence before taking the bread and the wine and repenting from all unrepented sins. Thirdly, by emphasizing silence, solemnity and contemplation, the Eucharist is something vertical and individualistic because our communion is with the Lord and only accidentally with others.

When we put into practice all that Hicks (2010) talks about, then a celebration of the Eucharist in an average Evangelical church looks like this: "There is no movement by those who eat and drink other than the servers. Communicants are served as they sit silently in their pews contemplating the cross of Christ. There they , silently, solemnly, sublimely' proclaim the Lord's death till he comes. In other words, it is an anthropocentric and individualistic legal duty performed in memory and proclamation of the death of Jesus."

Based on our assessment, it seems that even though the Eucharist in Evangelical Churches is defined as the table, and even though de iure wthe Lord's Supper is a way of communing with each other and with Christ; it is a communal event of memory and proclamation that strengthens the unity of the church " (Olson 2008b, 154); de facto a celebration of the Eucharist does not reflect the form of the table but that of the altar.

"Altar is the dominant model for the supper in the contemporary church. It fosters individualism (privacy), silence, solemnity, and sorrow /.../ The altar is a place where the guilty bring their sins for atonement, but the table is where the forgiven experience communion with God. The altar is a place of death and sorrow, but the table is a place of hope (life) and joy. The believer seeks reconciliation at the altar, but experiences reconciliation at the table. /.../ The Lord's Supper is a meal eaten at a table. It is not a sacrifice offered at an altar." (Hicks 2002, 10; 185-186)

\section{Comparison of the Catholic and Evangelical eucharistic theology and ecclesial practice}

In our comparison of the Catholic and Evangelical Eucharistic theology and ecclesial practice, we started with their similarities and common views. Hence, in our discussion in the first part of the article, we tried to present the Eucharistic roots that both traditions drew from Jewish background. We briefly observed the meaning of meals in Jewish religious context and the early Church, the Passover as a unique historical event (a meal, memorial and feast for itself), and finally we presented the OT manna and the notions of the new manna and new Passover. 
However, taking into consideration the different theological understandings and diverse further developments of the above-mentioned common foundations and sources, we can say that the Eucharist is spiritually in the center of the Catholic worship service, while the altar is physically in the center of the sacred liturgical (worship) space. It is interesting, for example, to compare the place of the altar in a Catholic Church and in an Evangelical Church because we can immediately notice a significant difference - Evangelical Churches have a pulpit and do not have any altar whatsoever, while Catholic Churches have both an altar and a pulpit (ambo). Therefore, while the pulpit in Evangelical Churches is a place for both the service of the Word and is usually a starting point for the administering of the sacrament of the Eucharist, in Catholic Churches these two services are separated: the reading and preaching of the Word primarily happens at the ambo, while the Lord's sacrifice in the species of the bread and wine is presented at the altar and then administered to the believers in the church in the form of a host. ${ }^{10}$

What might perhaps be a ,challenging' issue for an Evangelical believer here is that the Eucharist is an essential element of the Catholic worship service (the Mass), while the homily (sermon, preaching) is not. The homily is "strongly recommended, for it is necessary for the nurturing of the Christian life. /.../ There is to be a homily on Sundays and holy days of obligation at all Masses that are celebrated with the participation of a congregation; it may not be omitted without a serious reason. " Regarding other days, however, it is only recommended, "especially on the weekdays of Advent, Lent, and the Easter Season, as well as on other festive days and occasions when the people come to church in greater numbers" (General Instruction of the Roman Missal, nr. 65-66).

In the Evangelical ecclesial practice, partaking in and administering the sacrament of the Eucharist is diverse. We can roughly divide it into two groups. In some Churches, all those present who recognize for themselves that they are sinners and are willing to accept the Lord's graceful invitation to his table are welcome to participate in the sacrament, while they do not need to be members of an Evangelical church or even previously baptized. In this case, their recognition that they need the Lord's grace in their life is enough for partaking in the Eucharist. However, in some other Evangelical Churches, only those who are members of that particular church (or any other Evangelical church), who were baptized as adults, not as infants, when they were able to freely and publicly confess their faith, can partake in the Eucharist but only if they previously confessed their sins to God and asked for His forgiveness, and also if they are reconciled with those who are their neighbors.

In Catholic ecclesial practice, the partaking in the Eucharist is strictly prescribed and allowed to "any baptized person not prohibited by law«. However, "those who have been excommunicated or interdicted after the imposition or declara-

10 Additionally, in Evangelical Churches a pastor, but also a lay person, may preside over the Eucharist, while in the Catholic ecclesial practice that role is reserved for clergy only. For the discussion whether viri probati in the Catholic Church can preside over the Eucharist and how that might affect theological discussion about the concept of the priestly ministry in the Church, see Raczyński-Rożek 2018. 
tion of the penalty and others obstinately persevering in manifest grave sin are not to be admitted to holy communion ", while also "a person who is conscious of grave $\sin$ is not to celebrate Mass or receive the body of the Lord without previous sacramental confession unless there is a grave reason and there is no opportunity to confess " (Code of Canon Law, Cann. 912; 915; 916). Moreover, " wafter being initiated into the Most Holy Eucharist, each of the faithful is obliged to receive holy communion at least once a year" (Can. 920.1).

Therefore, we can conclude that the communion of believers (fellowship) and the Holy Communion (the Eucharist) are interrelated in a such a way that the altar and the sacrifice bind the believers together into fellowship with each other and with God at Christ's table in the eating of his very Body and drinking of his very Blood. There is no full communion (fellowship) of believers without gathering around the altar, which in a way becomes the table of fellowship by partaking in the Sacrifice.

Let us now turn to Evangelicals. Since the Evangelicals focus on the preaching of the Word in their Sunday services, the Eucharist is not something that is observed every Sunday in most Evangelical Churches. But even when the Eucharist is observed, it is observed with an ,altar mentality. Hence, if Evangelical Churches want to be faithful to their ,table theology' of the Eucharist, they must align their practice to reflect a ,table mentality', and that requires two things: a) to rethink the relationship between the altar and the table and $b$ ) to rethink the presence of Christ in the Eucharist.

The question is, why do Evangelical Churches mostly approach the Eucharist as an altar, when theologically for them it is a table? An altar is a place where reconciliation is sought and where the guilty party must bring forth his or her sins for atonement. It is a place where guilt comes with remorse and one seeks forgiveness and restoration of the relationship in remorse. Once that is achieved and the sacrifice is made, the restored party is free to sit at the table to enjoy and celebrate the restored relationship with God and/or men. Therefore, for Evangelicals, the table is and should be something that comes after the altar. You cannot have a table without an altar, but once a sacrifice is made and the relationship is restored, the table becomes a celebration of that what had occurred at the altar.

The issue of Christ's presence in the Eucharist is also challenging. Evangelicals do not view Christ's presence in the elements of the Eucharist but in each individual believer. Therefore, the focus is not on Christ, in the bread and wine', but on the ,Christ in believers'. However, since the Eucharist is viewed mostly through the altar mentality, the communion predominantly happens between ,Christ and me'. This individualistic fellowship could be reversed if we would recognize the presence of Christ, our host, at the table. Hence, Hicks says: "Christ sits at the table with us rather than primarily locating himself in the bread and wine. The bread and wine evoke the memory of Christ's work, but the table is the presence of Christ as one who eats and drinks with us." (2010a, 74)

Since the Evangelicals are not bound by a specific form of (official) liturgy, the 
form of the Eucharist can be revised to "foster community, interactive communication, gratitude and joy $(2002,10)$. In the context of the Sunday worship services, this revision should include a table and a full meal. Besides returning the elements of the bread and wine back in the context of agape feasts, this setting would replace the individualistic and sorrowful atmosphere and would instead foster thanksgiving, joy and mutual communication. And even though the New Testament does not prescribe how often the Eucharist must be observed, it seems that there is no argument strong enough saying why the Eucharist should not become a regular part of every church service. In this way, Evangelical Churches can practice the Eucharist eaten at the table as a meal and keep the bread and the wine in its center.

\section{Conclusion}

As we come to a conclusion, let us repeat that in this article we did not argue for the correctness of any specific approach; our attempt was to present each view faithfully, notice the similarities and differences between them and see to what extent each view is faithful to its position or settings. Based on our findings, we were able to come to the following conclusion: the Catholic Church and Evangelical Churches do not practice the Eucharist as a full meal, taking the bread and wine in the context of a table/meal fellowship. For the Catholic Church, Christ is present in the elements of the bread and wine, hence, the Eucharist is at the center of the Mass. It is predominately described and understood as a sacrifice, and this sacrifice is linked with the Lord's Table, which creates a communion. This communion or fellowship is not connected with an actual full meal, but with the idea of the believer's communion with Christ, which then produces a communion among the people. On the other hand, although Evangelical Churches view the presence of Christ in the believers and not in the bread and wine, and they theologically view the Eucharist as ,coming to the table of the Lord', in reality, their celebration of the Eucharist happens in the form of an altar, as a predominately individualistic and pious activity. This is why some Evangelicals can take communion by themselves.

Even though major irreconcilable differences exist in the theology of the Eucharist between the Catholic Church and Evangelical Churches, in practice both traditions use a similar approach - the so-called ,altar approach'. The Catholic Church is faithful to its teaching and understanding of the Eucharist where the sacrificial presence of Christ in the Eucharist produces, a mysterious fraternization of the heaven and the earth'. Evangelical Churches, on the other hand, display inconsistency when they treat the Eucharist as a ,table', but observe it more like an ,altar'. If this inconsistency were to be recognized, Evangelicals would be free to address it and make the Eucharist more horizontally communal - more like a table. 


\section{References}

Allison, Gregg, and Chris Castaldo. 2017. Nedovršena reformacija: Što ujedinjuje i razdvaja katolike i protestante nakon 500 godina. Dallas: Eastern European Mission.

Catechism of the Catholic Church. 1992. Holy see. http://www.vatican.va/archive/ENG0015/_INDEX.HTM (accessed 10. 11. 2020).

Chappell, Paul G. 1984. Heal, healing. In: Walter A. Elwell, ed. Evangelical dictionary of theology, 497-498. Grand Rapids: Baker Book House.

Code of Canon Law. 1983. Holy see. https://www. vatican.va/archive/ENG1104/_INDEX.HTM (accessed 4. 7. 2020).

Feeley-Harnik, Gillian. 1994. The Lord's table: The meaning of food in early Judaism and Christianity. Washington: Smithsonian Institution Press.

General Instruction of the Roman Missal. 1969. Holy see. http://www.vatican.va/roman_curia/congregations/ccdds/documents/rc_con_ccdds_ doc_20030317_ordinamento-messale_en.html\#B. The_Liturgy_of_the_Word_(accessed 4. 7. 2020)

Hicks, John Mark. 2002. Come to the table: Revisioning the Lord's supper. Abilane: Leafwood Publishing.

- - - 2010a. Churches of Christ and the Lord's supper: Twentieth-century perspectives. Stone-Campbell Journal 13, no. 2:163-176.

- - - 2010b. The practice of the table in 20th century Churches of Christ. John Mark Hicks, 11. 3. http://johnmarkhicks.com/2010/03/11/ the-practice-of-the-table-in-20th-century-Churches-of-christ/ (accessed 6. 6. 2020).

Ikić, Niko. 2014. Communio i Successio u teologiji Petrove službe. Diacovensia: Teološki Prilozi 22, no. 2:219-231.

Jambrek, Stanko. 2003. Crkve reformacijske baštine u Hrvatskoj. Zagreb: Bogoslovni institut.

- - - 2008. The great commission in the context of the Evangelical churches of Croatia in the second part of the twentieth century. Kairos 2, no. 2:153-179.

Jones, Ivor H., and Edward Kessler. 2005. Eucharist. In: Edward Kessler and Wenborn Neil, eds. A dictionary of Jewish-Christian relations, 14749. Cambridge: Cambridge University Press.

Kärkkäinen, Veli-Matti. 2008. The Pentecostal view. In: Gordon T. Smith, ed. The Lord's supper: five views, 167-200. Downers Grove: InterVarsity Press.

Kugler, Yizchak. 2008. The Lord's supper in the breaking of bread. Teaching from Zion 24, (August): 18-20.

Levering, Matthew. 2005. Sacrifice and community: Jewish offering and Christian eucharist. Malden: Wiley-Blackwell.
McGowan, Andrew. 1999. Ascetic eucharists: Food and drink in early Christian ritual meals. Oxford; New York: Clarendon Press.

Merritt, Jonathan. 2015. Defining, Evangelical'. The Atlantic, 7. 12. https://www.theatlantic. com/politics/archive/2015/12/evangelical-christian/418236/ (accessed 8. 11. 2020).

Olson, Roger E. 2008a. A Baptist response. In: Gordon T. Smith, ed. The Lord's supper: Five views, 208-210. Downers Grove: InterVarsity Press.

- - . 2008b. The Baptist view. In: Gordon T. Smith, ed. The Lord's supper: Five views, 125154. Downers Grove: InterVarsity Press.

Olson, Roger E., ed. 2005. The SCM Press A-Z of Evangelical theology. London: SCM Press.

Perry, John M. 1994. Exploring the evolution of the Lord's supper in the New Testament. Kansas City: Sheed \& Ward.

Pitre, Brant. 2011. Jesus and the Jewish roots of the eucharist: unlocking the secrets of the last supper. New York: Image.

Raczyński-Rożek, Maciej. 2018. Viri probati and presiding over the eucharist according to Edward Schillebeeckx. Bogoslovni vestnik 78, no. 1:105-119.

Ratzinger, Joseph. 1988. Eschatology: Death and eternal life. Translated by Michael Waldstein. Washington, D.C.: The Catholic University of America Press.

- - - 2006. Zajedništvo u Crkvi. Translated by Ivan Ivanda. Split: Verbum.

---. 2007. Eucharist, communion, and solidarity-Lecture given at the eucharistic congress of the Archdiocese of Benevento, Italy (June 2, 2002). In: John F. Thornton and Susan B. Varenne, eds. The essential Pope Benedict XVI: His central writings and speeches, 69-84. San Francisco: Harper San Francisco.

- - . 2011. Dogma i navještaj. Translated by Ivan Ivanda. Zagreb: Kršćanska sadašnjost.

Thomas Aquinas. The Summa Theologica. Translated by Fathers of the English Dominican Province. Cooperatorum Veritatis Societas. http://www.documentacatholicaomnia.eu/03d/1225-1274,_Thomas_Aquinas,_Summa_Theologiae_\%5B1\%5D,_EN.pdf (accessed 4. 7. 2020).

Turnbloom, David Farina. 2017. Speaking with Aquinas: A conversation about grace, virtue, and the eucharist. Collegeville: Liturgical Press.

World Council of Churches. 2020. Evangelical Churches. World Council of Churches. https:// www.oikoumene.org/church-families/evangelical-Churches (accessed 11. 9. 2020)

Yuval, Israel Jacob. 2008. Two nations in your womb: Perceptions of Jews and Christians in Late Antiquity and the Middle Ages. Translated by Barbara Harshav and Jonathan Chipman. Berkeley: University of California Press. 